\title{
On the effects of deoxynivalenol (DON) in pig feed on growth performance, nutrients utilization and DON metabolism*
}

\author{
S. Dänicke ${ }^{1,3}$, T. Goyarts' ${ }^{1}$ H. Valenta ${ }^{1}$, E. Razzazi ${ }^{2}$ and J. Böhm² \\ 'Institute of Animal Nutrition, Federal Agricultural Research Centre (FAL) \\ Bundesallee 50, 38116 Braunschweig, Germany \\ ${ }^{2}$ Institute of Nutrition, Veterinary University of Vienna \\ Veterinärplatz 1, A-1210 Vienna, Austria
}

(Received 27 October 2003; revised version 14 July 2004; accepted 25 October 2004)

\section{ABSTRACT}

Control wheat and wheat artificially inoculated with Fusarium culmorum and as well as wheat contaminated mainly with deoxynivalenol (DON) were gradually blended to yield diets for pigs with increasing DON concentrations $(0.2,0.7,1.2,2.5,3.7 \mathrm{mg} / \mathrm{kg})$ at a total wheat content of $400 \mathrm{~g} /$ $\mathrm{kg}$ diet. Performance was recorded over a liveweight range between 34 and $104 \mathrm{~kg}$ ( $\mathrm{n}=18$ per group). Blood was drawn from the jugular vein after five weeks on the experimental diets to determine the clinical-chemical parameters and DON concentrations. In addition, a balance study was carried out with the groups fed the diets with the lowest and the highest DON concentration to test the effects on nutrient digestibility and DON metabolism. DON and its metabolite de-epoxy-DON were analysed in physiological samples by HPLC after cleanup by immuno-affinity columns (IAC).

Performance of pigs was not significantly affected by increasing dietary DON concentrations, although there was a trend toward a decrease in weight. This was especially true for the group fed the diet with $3.7 \mathrm{mg} \mathrm{DON} / \mathrm{kg}$, which consumed $5 \%$ less feed and gained $8 \%$ less liveweight than the control group. Serum clinical-chemical parameters, such as albumin, total protein, GLDH, ASAT, $\gamma$-GT and immunoglobulins were not influenced by the dietary treatments. DON concentration in serum increased in a dose-response-related manner and did clearly reflect the DON exposure of the animals. However, adverse effects on performance were only obvious for the group fed the diet with the highest DON concentration.

No significant differences were found for nutrient digestibility of the tested diets. With regard to the DON balance and metabolism, urine was the main excretory route. A total of $52.3 \%$ of the ingested DON was eliminated as the parent toxin whereas $2.6 \%$ was excreted as the metabolite de-epoxyDON in the group fed the diet with $3.7 \mathrm{mg}$ DON $/ \mathrm{kg}$. The excretion of both substances accounted for

\footnotetext{
"Supported in part by the Deutsche Forschungsgemeinschaft, DFG-project DA 558/1-1

${ }^{3}$ Corresponding author: e-mail: sven.daenicke $(a)$ fal.de
} 
approximately $98 \%$ of the total DON recovery from urine and faeces, which indicates the important role of the urinary elimination route. De-epoxy-DON accounted for approximately $5 \%$ of the urinary excretion of de-epoxy-DON plus DON, whereas in faeces a ratio of approximately $97 \%$ was found, which underlines the role of the digestive tract in the metabolism of DON in the pig.

KEY WORDS: pig, deoxynivalenol, metabolism, performance, nutrient utilization

\section{INTRODUCTION}

The former German Ministry of Nutrition, Agriculture and Forestry published orientation values for critical dietary concentrations of deoxynivalenol (DON) for farm animals and recommended not exceeding $1 \mathrm{mg}$ DON per $\mathrm{kg}$ pig diet in order to avoid detrimental effects on health and performance (BML, 2000). Dänicke et al. (2001) compiled published data and derived a linear relationship between dietary DON concentration and the relative change of feed intake and liveweight gain of growing pigs compared to the control group fed an uncontaminated diet. From the negative linear regression it could be predicted that feed intake decreases by $4 \%$ when dietary DON concentration increases by $1 \mathrm{mg} / \mathrm{kg}$. However, it was also found that this relationship does not exist when the dietary DON concentration is less than $1 \mathrm{mg} / \mathrm{kg}$, since negative, neutral and positive effects of low, and practically relevant, DON concentrations were reported. The reasons for these controversial findings could not be fully explained by differing experimental conditions, such as sex or breed of the pigs, age or duration of the experiments or source of DON (pure, standard, naturally contaminated grain). On the other hand, field observations often suggest lower critical DON concentrations than derived from experiments. Hence, the validity of a critical DON concentration as discussed is quite controversial. For this reason, a dose-response study with fattening pigs was carried out to cover practically relevant dietary DON concentrations lower and higher than $1 \mathrm{mg} / \mathrm{kg}$ diet. Moreover, the effects of the DON presence in the diet on nutrient utilization and DON metabolism were also examined to get a better understanding of the overall effects of DON on pigs.

\section{MATERIAL AND METHODS}

\section{Experimental design}

Control wheat and wheat artificially inoculated with Fusarium culmorum and as well as wheat contaminated mainly with DON were gradually blended increase dietary DON concentration at a total constant wheat content of $400 \mathrm{~g} / \mathrm{kg}$ diet. Based on the analysed DON concentration of the contaminated wheat, the dietary DON concentrations were adjusted to $0,0.34,0.69,1.37$ and $2.74 \mathrm{mg} / \mathrm{kg}$ diet (Table 1). 
TABLE 1

Composition of the experimental diets, $\mathrm{g} / \mathrm{kg}$, based on a DM content of $88 \%$

\begin{tabular}{|c|c|c|c|c|c|c|c|c|c|c|}
\hline & \multicolumn{10}{|c|}{ Group } \\
\hline & \multicolumn{2}{|c|}{1} & \multicolumn{2}{|c|}{2} & \multicolumn{2}{|c|}{3} & \multicolumn{2}{|c|}{4} & \multicolumn{2}{|c|}{5} \\
\hline & starter & finisher & starter & finisher & starter & finisher & starter & finisher & starter & finisher \\
\hline \multicolumn{11}{|l|}{ Ingredients } \\
\hline barley & 348 & 446 & 348 & 446 & 348 & 446 & 348 & 446 & 348 & 446 \\
\hline wheat & 400 & 400 & 350 & 350 & 300 & 300 & 200 & 200 & 0 & 0 \\
\hline contaminated wheat & 0 & 0 & 50 & 50 & 100 & 100 & 200 & 200 & 400 & 400 \\
\hline soyabean meal & 200 & 110 & 200 & 110 & 200 & 110 & 200 & 110 & 200 & 110 \\
\hline soyabean oil & 20 & 15 & 20 & 15 & 20 & 15 & 20 & 15 & 20 & 15 \\
\hline dicalcium-phosphate & 3.5 & 1 & 3.5 & 1 & 3.5 & 1 & 3.5 & 1 & 3.5 & 1 \\
\hline $\mathrm{NaCl}$ & 1 & 0.5 & 1 & 0.5 & 1 & 0.5 & 1 & 0.5 & 1 & 0.5 \\
\hline L-lysine-HCL & 2.5 & 2.5 & 2.5 & 2.5 & 2.5 & 2.5 & 2.5 & 2.5 & 2.5 & 2.5 \\
\hline premix $^{1}$ & 25 & 25 & 25 & 25 & 25 & 25 & 25 & 25 & 25 & 25 \\
\hline \multicolumn{11}{|l|}{ Calculated composition } \\
\hline crudc protein & 173 & 143 & 173 & 143 & 173 & 143 & 173 & 143 & 173 & 143 \\
\hline $\mathrm{ME}(\mathrm{MJ} / \mathrm{kg})$ & 131 & 130.5 & 131 & 130.5 & 131 & 130.5 & 131 & 130.5 & 131 & 130.5 \\
\hline lysine & 10.1 & 8.1 & 10.1 & 8.1 & 10.1 & 8.1 & 10.1 & 8.1 & 10.1 & 8.1 \\
\hline methionine + cystine & 5.7 & 5 & 5.7 & 5 & 5.7 & 5 & 5.7 & 5 & 5.7 & 5 \\
\hline threonine & 5.9 & 4.8 & 5.9 & 4.8 & 5.9 & 4.8 & 5.9 & 4.8 & 5.9 & 4.8 \\
\hline tryptophan & 2.1 & 1.8 & 2.1 & 1.8 & 2.1 & 1.8 & 2.1 & 1.8 & 2.1 & 1.8 \\
\hline $\mathrm{Ca}$ & 9.4 & 8.5 & 9.4 & 8.5 & 9.4 & 8.5 & 9.4 & 8.5 & 9.4 & 8.5 \\
\hline total P & 6.4 & 5.7 & 6.4 & 5.7 & 6.4 & 5.7 & 6.4 & 5.7 & 6.4 & 5.7 \\
\hline $\mathrm{Na}$ & 2.1 & 1.9 & 2.1 & 1.9 & 2.1 & 1.9 & 2.1 & 1.9 & 2.1 & 1.9 \\
\hline deoxynivalenol, $\mathrm{mg} / \mathrm{kg}$ & 0.00 & 0.00 & 0.34 & 0.34 & 0.69 & 0.69 & 1.37 & 1.37 & 2.74 & 2.74 \\
\hline \multicolumn{11}{|l|}{ Analysed composition } \\
\hline crude protein & 179 & 145 & 176 & 149 & 174 & 145 & 176 & 150 & 176 & 143 \\
\hline deoxynivalenol, $\mathrm{mg} / \mathrm{kg}$ & 0.15 & 0.18 & 0.76 & 0.58 & 1.14 & 1.30 & 2.60 & 2.49 & 3.86 & 3.46 \\
\hline
\end{tabular}

${ }^{3}$ provided per kg of diet: $\mathrm{Ca}, 6.1 \mathrm{~g} ; \mathrm{P}, 1.5 \mathrm{~g} ; \mathrm{Na}, 1.4 \mathrm{~g} ; \mathrm{Mg}, 0.3 \mathrm{~g} ; \mathrm{Fe}, 100 \mathrm{mg}$; Cu, $25 \mathrm{mg}$; Mn, $50 \mathrm{mg} ; \mathrm{Zn}, 100 \mathrm{mg} ; \mathrm{I}, 1.3 \mathrm{mg} ; \mathrm{Se}, 0.4 \mathrm{mg} ; \mathrm{Co}, 0.5$ mg; vit. A, $10000 \mathrm{IU}$; vit. $\mathrm{D}_{3}, 1000 \mathrm{IU}$; vit. $\mathrm{E}, 30 \mathrm{mg}$; vit. $\mathrm{B}_{1}, 0.9 \mathrm{mg}$; vit. $\mathrm{B}_{2}, 2.5 \mathrm{mg}$; vit. $\mathrm{B}_{6}, 2.5 \mathrm{mg}$; vit. $\mathrm{B}_{12}, 18.8 \mu \mathrm{g}$; vit. $\mathrm{K}_{3}, 1.3 \mathrm{mg}$; nicotinic acid, $12.5 \mathrm{mg}$; pantothenic acid, $8.4 \mathrm{mg}$; choline chloride, $125 \mathrm{mg}$ 
Consequently, the so-calculated total dietary DON concentrations do not include possible DON contamination of other dietary components. The wheat proportions were kept constant over the whole experiment, whereas the proportion of barley was increased and soyabean meal proportion decreased in the finisher diets to adjust to the lower protein needs of the pigs during this fattening period (Table 1). Starter diets were fed for the first five weeks (average liveweight range between 34 and $68 \mathrm{~kg}$ ) of the experiment, and finisher diets thereafter until the end of the experiment after ten weeks (average liveweight range between 68 and $104 \mathrm{~kg}$ ).

With the exception of the fungus inoculation and the lack of fungicide treatment, the inoculated wheat and the control wheat were treated similarly. Both batches were of the same variety, "Ritmo", and produced on the same plot where similar agri-technical measures were applied. Thus, the observed effects of the control and contaminated wheat batches so-produced can be ascribed solely to the effects of the growth and metabolism, including the synthesized secondary metabolites (mycotoxins) of $F$. culmorum. Further details of the field study are described by Matthäus et al. (2004).

\section{Growth experiment}

Performance of fattening pigs (Deutsches Bundeshybridzuchtprogramm) was recorded over an average liveweight $34.1 \pm 4.1 \mathrm{~kg}$ to $103.7 \pm 9.4 \mathrm{~kg}$ ( $\mathrm{n}=18$ per group, 9 male castrates and 9 females). Pigs were kept in floor pens without bedding according the Danish system of stabling. Two pigs were kept together in such a way that feed was offered in one pen for ad libitum consumption and water in the neighboring pen. Thus, pigs had permanent access to both pens. Such housing was necessary since nipple drinkers were located above the trough and would have made dry ad libitum feeding impossible. Feed consumption and liveweight were recorded weekly until the 70 th day, when the experiment was terminated.

After five weeks on the experimental diets blood was drawn from the vena jugularis from all males (9 per group) and clinical-chemical parameters and DON concentration were determined in serum.

\section{Balance study}

In addition, a balance study was carried out with the groups fed the starter diets with the lowest and the highest DON concentration on nutrient digestibility and DON metabolism.

The balance study was carried out according to the total collection method as described by Schiemann (1981). Each diet was tested on five barrows which were not involved in the growing experiment. Daily DM intake was restricted to an amount consumed by all animals and which was equivalent to the maximum level voluntarily consumed by the pigs fed the DON containing diet. Pigs were 
adjusted to the diets and the balance cages during a pre-period lasting seven days which was followed by the seven-day-collection period. The mean liveweight of the pigs during the balance study was $75 \mathrm{~kg} \pm 5 \mathrm{~kg}$. The daily feed amount of 2.2 $\mathrm{kg}$ was fed in two equal portions at $7.00 \mathrm{a} . \mathrm{m}$. and $2.00 \mathrm{p} . \mathrm{m}$. h after collecting the faeces. Faeces were homogenized at the end of the collection period and a sample was freeze dried and ground to pass through a $1 \mathrm{~mm}$ screen.

\section{Analyses}

Freeze dried faeces samples and feed samples were analysed for crude nutrients according to the methods of the Association of German Agricultural Study and Research Centres (Naumann and Bassler, 1993).

The DON content in wheat and diets was analysed by HPLC with DAD (diode array detection) after a cleanup with IAC (immuno-affinity column, VICAM) by a modified VDLUFA-method according to Valenta et al. (2002). The detection limit was $0.03 \mathrm{mg} / \mathrm{kg}$. The recovery was approximately $90 \%$ for these matrices. Further trichothecenes in wheat were analysed using a GC-MS-method (Schollenberger et al., 1998). Zearalenone in wheat was determined by a modified VDLUFA-HPLC method with fluorescence detection as described by Valenta (1999).

The determination of DON and de-epoxy-DON in urine, serum and freeze dried faeces is described by Valenta et al. (2003). Briefly, freeze dried faeces were analysed in principle as described for wheat and diets. Urine and serum samples were extracted with ethyl acetate on a ChemElut cartridge (Varian) (urine samples after incubation with $\beta$-glucuronidase), cleaned up by IAC (VICAM) and measured by HPLC-DAD. Comparative analyses of serum and faeces samples after treatment with $\beta$-glucuronidase and without enzyme treatment yielded similar DON concentrations. In contrast, the DON concentration was higher in urine samples after treatment with $\beta$-glucuronidase. Therefore, only the urine samples were treated with $\beta$-glucuronidase prior to further sample preparation. Reported analytical results comprise therefore the total DON concentration, including the free and conjugated toxin. No attempts were made to determine the proportions of free and conjugated DON present in urine.

The detection limits for both substances were approximately $0.02 \mathrm{mg} / \mathrm{kg}$ for faeces and $0.004 \mathrm{mg} / \mathrm{L}$ for urine and serum. The mean recovery of DON and de-epoxy-DON was $89 / 85 \%$ in serum, $82 / 81 \%$ in urine and $83 / 64 \%$ in faeces, respectively.

The so-analysed DON and de-epoxy-DON concentrations in physiological samples were confirmed by HPLC/MS in selected samples at the Institute of Nutrition of the Veterinary University of Vienna (Austria).

Activities of glutamate dehydrogenase (GLDH) (Schmidt, 1970), $\gamma$-glutamyltransferase $(\gamma-\mathrm{GT})$, (Labor + Technik, Eberhard Lehmann, Berlin, Szasz et al., 1974), aspartate aminotransferase (ASAT) (Labor + Technik, Eberhard Lehmann, Berlin, opt. DGKC) were measured in serum by enzymatic UV-standard 
procedures. Albumin concentration in serum was determined by the bromocresol green method (Labor + Technik, Eberhard Lehmann, Berlin) and that of total protein by the biurette method.

Concentrations of serum immunoglobulins IgG, IgA and IgM were determined by a simple radial immuno-diffusion method as described by Mancini et al. (1965) and Klobasa et al. (1983). The diffusion circles were measured after $24 \mathrm{~h}$ for IgG and IgA and after $48 \mathrm{~h}$ for IgM. The necessary anti-sera were obtained by immunization of dwarf goats, subsequently purified by affinity chromatography and tested for mono-specificity according to Klobasa et al. (1983) and Klobasa (1987). The reproducibility of the method is $95 \%$.

\section{Calculations and statistics}

Apparent digestibility of nutrients and balance of nitrogen and DON were calculated from the balance between intake and excretion. ME concentration of the diets was estimated using the prediction equation based on apparent digestible nutrients as proposed by the Committee for Requirement Standards of the Society for Nutritional Physiology (1987).

DON- and de-epoxy-DON concentrations in physiological samples which were lower than the above indicated that detection limits were considered with a concentration of zero in evaluating the data. This implies that calculated mean values might be lower than the detection limits.

Data were subjected to analysis of variance (ANOVA) according to a onefactorial design:

$$
\mathrm{y}_{\mathrm{ij}}=\mu+\mathrm{a}_{\mathrm{i}}+\mathrm{e}_{\mathrm{ij}}
$$

where $y_{i j}=j^{\text {th }}$ observation related to DON level $i ; \mu=$ overall mean; $a_{i}=$ effect of dietary DON level; $\mathrm{e}_{\mathrm{ij}}=$ error term.

Significant mean value differences were evaluated by the Tukey test. Mean value differences from the balance data (two groups only) were tested for significance by a simple t-test.

All statistics were carried out using the Statistica for the Windows ${ }^{\mathrm{TM}}$ operating system (StatSoft Inc., 1994).

\section{RESULTS}

\section{Wheat characteristics}

Inoculation of wheat with Fusarium culmorum resulted in a marked accumulation of deoxynivalenol of approximately $7.8 \mathrm{mg} / \mathrm{kg}$ DM whereas only $0.19 \mathrm{mg} / \mathrm{kg}$ were 
measured in the wheat batch harvested from the control plot. Besides the predominating DON, the acetylated derivative 3-acetyl-DON also was detected at a concentration of $1.6 \mathrm{mg} / \mathrm{kg}$ in the inoculated wheat. Furthermore, traces of 15-acetyldeoxynivalenol, nivalenol and scirpentriol were found in the inoculated wheat (Table 2).

TABLE 2

Wheat characteristics

\begin{tabular}{|c|c|c|}
\hline & Wheat & DON-wheat \\
\hline Crude protein, $\mathrm{g} / \mathrm{kg}$ DM & 131 & 142 \\
\hline \multicolumn{3}{|l|}{ Amino acids, g/kg DM } \\
\hline cystine & 3.1 & 3.0 \\
\hline methionine & 2.0 & 2.2 \\
\hline aspartic acid & 6.9 & 7.5 \\
\hline threonine & 3.9 & 4.0 \\
\hline serine & 6.2 & 6.1 \\
\hline glutamic acid & 24.9 & 26.4 \\
\hline proline & 12.0 & 12.4 \\
\hline glycine & 5.3 & 5.5 \\
\hline alanine & 4.7 & 5.1 \\
\hline valine & 5.8 & 6.2 \\
\hline isoleucine & 4.6 & 4.8 \\
\hline leucine & 9.1 & 9.3 \\
\hline thyrosine & 3.4 & 2.6 \\
\hline phenylalanine & 6.6 & 6.9 \\
\hline histidine & 3.3 & 3.5 \\
\hline lysine & 4.7 & 4.8 \\
\hline arginine & 6.6 & 6.7 \\
\hline Crude ash, g/kg DM & 16 & 18 \\
\hline Starch, g/kg DM & 713 & 703 \\
\hline Total NSP, g/kg DM & 89 & 97 \\
\hline Insoluble NSP, $\mathrm{g} / \mathrm{kg}$ DM & 77 & 74 \\
\hline Soluble NSP, g/kg DM & 12 & 24 \\
\hline Water extract viscosity, $\mathrm{mPas}$ & 2.2 & 1.5 \\
\hline \multicolumn{3}{|l|}{$\mu \mathrm{g} / \mathrm{kg} \mathrm{DM}$} \\
\hline Deoxynivalenol & 190 & 7790 \\
\hline Zearalenone & 2 & 100 \\
\hline Nivalenol & 24 & 45 \\
\hline Scirpentriol & $<9$ & 67 \\
\hline T2-tetraol & $<8$ & $<8$ \\
\hline Fusarenon-X & $<21$ & $<21$ \\
\hline Monoacetoxyscirpenol & $<3$ & $<3$ \\
\hline 15-acetyldeoxynivalenol & $<8$ & 12 \\
\hline 3-acetyldeoxynivalenol & $<10$ & 1573 \\
\hline T2-triol & $<6$ & $<6$ \\
\hline Neosolaniol & $<7$ & $<7$ \\
\hline Diacetoxyscirpenol & $<16$ & $<16$ \\
\hline HT-2 toxin & $<3$ & $<3$ \\
\hline $\mathrm{T}-2$ toxin & $<4$ & $<4$ \\
\hline
\end{tabular}


The zearalenone concentration of $0.1 \mathrm{mg} / \mathrm{kg} \mathrm{DM}$ in inoculated wheat was also increased compared to the control wheat where $0.002 \mathrm{mg} / \mathrm{kg}$ DM were measured. Changes in nutrient concentration caused by the growth of the fungus included a higher crude protein and amino acid concentration, higher ash content, an increased concentration of total and soluble NSP and decreased starch content. The water extract viscosity was lower in the contaminated wheat (Table 2).

\section{Methodological aspects of DON/de-epoxy-DON-analyses}

Principally, the analytical results of physiological samples for DON and de-epoxy-DON obtained by HPLC with DAD were comparable with those measured by HPLC coupled to an MS detector. The presence of de-epoxy-DON in faeces and urine and the absence of this metabolite in serum according to HPLC with DAD were confirmed by HPLC with MS. Moreover, relationships in DON/de-epoxy-DON concentrations in response to differing dietary treatments were comparable with both methods. For example, the DON concentration in the serum of six pigs fed the diets with $0.2,1.2$ and $3.7 \mathrm{mg} \mathrm{DON} / \mathrm{kg}$ (Groups 1 , 3 and 5, respectively, two pigs per treatment) was $<4,<4,6,8,22$ and $18 \mathrm{ng} / \mathrm{mL}$ according to HPLC-DAD, and $<2,<2,9,6,25$ and $24 \mathrm{ng} / \mathrm{mL}$ by HPLC-MS, respectively.

Thus, the HPLC method with DAD used provided reliable results and was used to analyse all samples in the present study.

\section{Growth experiment}

Performance was not significantly influenced by dietary DON concentration, although there were some tendencies which should not be overlooked (Table 3). Voluntary feed intake was not negatively influenced by the presence of DON in the diet, and a slight stimulation was even observed up to a contaminated wheat proportion of $20 \%$. Interestingly, feed intake tended to decline with increasing proportions of the contaminated wheat during the finishing period and nearly reached significance $(\mathrm{P}=0.065)$. Compared to the control group, feed intake was depressed by 5,3,6 and $9 \%$, respectively, during this period. This effect disappeared when the fattening period was considered in its entirety and remained only for the group fed the diet with the highest contaminated wheat with an overall depression effect of $5 \%$. 
TABLE 3

Performance of pigs exposed to graded levels of DON contaminated wheat $(\mathrm{n}=9$ for feed intake and feed to gain ratio, $n=18$ for liveweight gain)

\begin{tabular}{|c|c|c|c|c|c|c|c|c|c|}
\hline \multirow{2}{*}{$\begin{array}{l}\text { Contaminated } \\
\text { wheat proportion' } \\
\%\end{array}$} & \multicolumn{3}{|c|}{$\begin{array}{c}\text { Feed intake } \\
\mathrm{kg} / \mathrm{d}\end{array}$} & \multicolumn{3}{|c|}{$\begin{array}{c}\text { Liveweight gain } \\
\mathrm{kg} / \mathrm{d}\end{array}$} & \multicolumn{3}{|c|}{$\begin{array}{c}\text { Feed to gain ratio } \\
\mathrm{kg} / \mathrm{kg}\end{array}$} \\
\hline & starter & grower & total & starter & grower & total & starter & grower & total \\
\hline () & 2.28 & 3.29 & 2.78 & 1.02 & 1.04 & 1.03 & 2.25 & 3.17 & 2.71 \\
\hline 5 & 2.35 & 3.13 & 2.74 & 0.98 & 1.00 & 0.99 & 2.42 & 3.14 & 2.78 \\
\hline 10 & 2.42 & 3.19 & 2.80 & 0.99 & 1.04 & 1.01 & 2.45 & 3.10 & 2.77 \\
\hline 20 & 2.37 & 3.09 & 2.73 & 0.97 & 1.01 & 0.99 & 2.44 & 3.08 & 2.77 \\
\hline 40 & 2.28 & 2.99 & 2.64 & 0.94 & 0.95 & 0.95 & 2.46 & 3.15 & 2.79 \\
\hline $\begin{array}{l}\text { ANOVA } \\
\text { (probability) }\end{array}$ & 0.551 & 0.065 & 0.198 & 0.582 & 0.265 & 0.238 & 0.400 & 0.932 & 0.919 \\
\hline PSEM & 0.07 & 0.07 & 0.05 & 0.04 & 0.03 & 0.03 & 0.09 & 0.08 & 0.07 \\
\hline
\end{tabular}

PSEM - pooled standard error of means

Starter period: 34 to $68 \mathrm{~kg}$, grower period: 68 to $104 \mathrm{~kg}$ liveweight

${ }^{1}$ DON concentrations of the starter/grower diets: $0.15 / 0.18,0.76 / 0.58,1.14 / 1.30,2.60 / 2.49$, and $3.86 / 3.46 \mathrm{mg} / \mathrm{kg}$ for diets containing $0,5,10,20$ and $40 \%$ contaminated wheat, respectively

The effects of contaminated wheat on liveweight gain were less obvious, with the exception of the group exposed to the highest levels, which gained approximately 8 to $9 \%$ less than the control group. The feed to gain ratio was 8 to $9 \%$ higher for pigs fed the contaminated wheat regardless of the inclusion rate during the starter period as a result of the stimulated feed intake and the concomitant decrease in liveweight gain. In contrast, no effects or slight decreases became obvious during the finishing period due to parallel decreases in feed intake and liveweight gain. Effects of the starter and finisher period were compensated and resulted in no significant effects for the whole fattening period.

\section{Serum-clinical parameters}

DON concentration in serum increased linearly with the dietary inclusion of the contaminated wheat ( $\mathrm{P}$ for linear effect $<0.001$ ) whereas for all other parameters examined (serum concentration of albumin, total protein, immunoglobulins, serum activities of GLDH, $\gamma$-GT and ASAT) no significant treatment effects could be detected (Table 4). 
TABLE 4

Serum clinical-chemical parameters and DON concentration in serum of pigs exposed to graded levels of DON contaminated wheat for five weeks covering the liveweight range between approximately 34 and $68 \mathrm{~kg}(\mathrm{n}=9)$

\begin{tabular}{|c|c|c|c|c|c|c|c|c|c|}
\hline $\begin{array}{l}\text { Contaminated } \\
\text { wheat proportion } \\
\%\end{array}$ & $\begin{array}{l}\text { Albumin } \\
\mathrm{g} / \mathrm{L}\end{array}$ & $\begin{array}{c}\text { Total protein } \\
\mathrm{g} / \mathrm{L}\end{array}$ & $\begin{array}{l}\text { GLDH } \\
\mathrm{U} / \mathrm{L}\end{array}$ & $\begin{array}{c}\gamma-\mathrm{GT} \\
\mathrm{U} / \mathrm{L}\end{array}$ & $\begin{array}{l}\text { ASAT } \\
\text { U/L }\end{array}$ & $\underset{\mathrm{mg} / \mathrm{mL}}{\lg \mathrm{A}}$ & $\underset{\mathrm{Igg} / \mathrm{mL}}{\mathrm{IgM}}$ & $\underset{\mathrm{mg} / \mathrm{mL}}{\operatorname{lgG}}$ & $\begin{array}{l}\mathrm{DON} \\
\mathrm{ng} / \mathrm{mL}\end{array}$ \\
\hline 0 & 41.2 & 60.9 & 1.8 & 16.8 & 12.5 & 1.1 & 2.4 & 20.2 & $0.7^{\mathrm{a}}$ \\
\hline 5 & 40.2 & 61.2 & 2.3 & 20.4 & 15.2 & 1.4 & 2.3 & 19.8 & $1.2^{\mathrm{a}}$ \\
\hline 10 & 39.9 & 62.0 & 2.5 & 17.8 & 14.0 & 1.7 & 2.7 & 24.8 & $3.7^{\mathrm{b}}$ \\
\hline 20 & 41.3 & 60.5 & 2.2 & 19.4 & 15.0 & 1.3 & 2.7 & 20.9 & $11.9^{\mathrm{b}}$ \\
\hline 40 & 40.3 & 60.5 & 2.6 & 16.6 & 15.1 & 1.7 & 2.9 & 22.9 & $13.2^{\mathrm{b}}$ \\
\hline $\begin{array}{l}\text { ANOVA } \\
\quad \text { (probability) }\end{array}$ & 0.775 & 0.945 & 0.755 & 0.162 & 0.377 & 0.215 & 0.433 & 0.386 & $<0.001$ \\
\hline PSEM & 1.0 & 1.5 & 0.5 & 1.3 & 1.2 & 0.2 & 0.2 & 2.0 & 1.1 \\
\hline
\end{tabular}

PSEM - pooled standard error of means

${ }^{\mathrm{ab}}$ values with no common superscript are significantly different within columns $(\mathrm{P}<0.05)$

' DON concentrations of the starter/grower diets: $0.15 / 0.18,0.76 / 0.58,1.14 / 1.30,2.60 / 2.49$, and $3.86 / 3.46 \mathrm{mg} / \mathrm{kg}$ for diets containing $0,5,10,20$ and $40 \%$ contaminated wheat, respectively

\section{Metabolism of DON}

Both the parent toxin DON, and its de-epoxydized metabolite de-epoxy-DON, were detected in urine and faeces. Concentrations were significantly higher in pigs exposed to the diet containing DON as compared to the pigs fed the control diet (Table 5). Highest concentrations were measured in urine, where DON was the predominating compound, whereas relatively low concentrations of de-epoxyDON were found. In contrast, the opposite relationship between both compounds was observed in faeces, where de-epoxy-DON was the prevailing compound. The concentration of the metabolite was approximately five times lower than that of DON in urine.

Quantitatively, about 56 to $57 \%$ of the ingested DON was recovered as DON and de-epoxy DON in urine and feeces independent of the DON exposure of pigs. The majority of ingested DON was excreted as DON in the urine where 57 and $52 \%$ was recovered in pigs of the control group and of the DON exposed group, respectively. De-epoxy-DON was not detectable in urine of the control pigs whereas the DON concentration in faeces was lower than the detection limit.

The metabolite profile, expressed as a relative proportion of de-epoxy-DON excretion, of the excretion of the sum of de-epoxy-DON plus DON, was distinctly different for urine and faeces and amounted to 5 and $97 \%$, respectively, for pigs fed the contaminated diet. 
TABLE 5

Characteristics of DON excretion of pigs fed Fusarium toxin contaminated or not contaminated wheat based diets ( $\mathrm{n}=5$ per group)

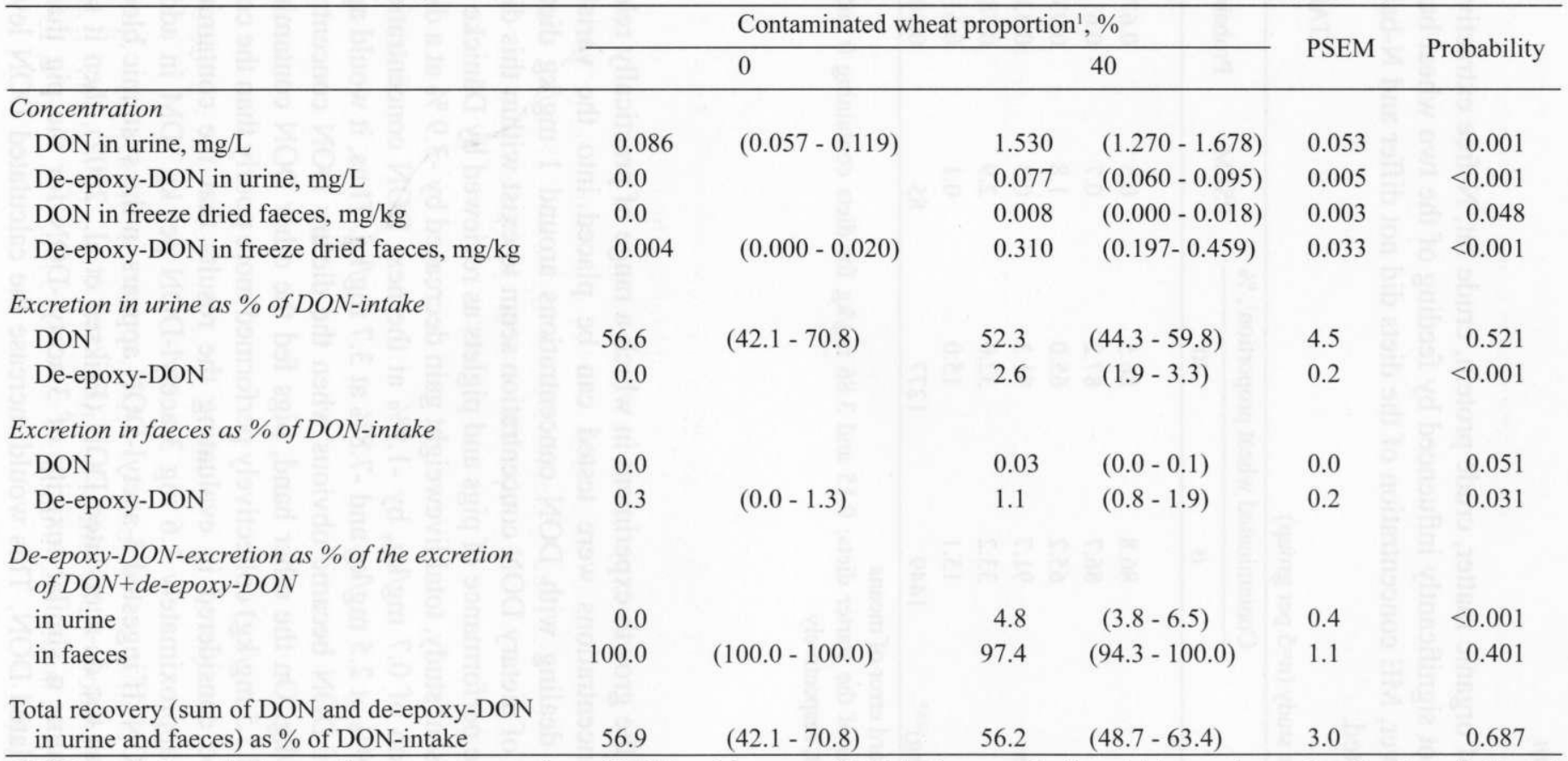

PSEM - pooled standard error of means concentrations of DON and de-epoxy-DON in faeces and urine which were lower than the above indicated detection limits were considered with a concentration of zero in evaluating the data which implies that calculated mean values might be lower than the detection limits

${ }^{1}$ DON concentrations of the starter diets: 0.15 and $3.86 \mathrm{mg} / \mathrm{kg}$ for diets containing 0 and $40 \%$ contaminated wheat, respectively 


\section{Nutrient utilization}

Digestibility of organic matter, crude protein, crude fat, $\mathrm{N}$-free extractives or crude fibre was not significantly influenced by feeding of the two wheat batches (Table 6). Moreover, ME concentration of the diets did not differ and $\mathrm{N}$-balance remained unaffected.

TABLE 6

Results of the balance study ( $\mathrm{n}=5$ per group)

\begin{tabular}{lcccc}
\hline & \multicolumn{2}{c}{ Contaminated wheat proportion', \% } & \multirow{2}{*}{ PSEM } & \multirow{2}{*}{ Probability } \\
\cline { 2 - 3 } & 0 & 40 & & \\
\hline Digestibility, \% & & & & \\
$\quad$ organic matter & 86.8 & 86.5 & 0.5 & 0.673 \\
crude protein & 86.7 & 87.2 & 0.7 & 0.612 \\
$\quad$ crude fat & 65.2 & 65.0 & 1.8 & 0.937 \\
$\quad$ N-free extractives & 91.7 & 91.3 & 0.3 & 0.333 \\
$\quad$ crude fibre & 33.2 & 32.0 & 2.9 & 0.788 \\
ME, MJ/kg DM & 15.1 & 15.0 & 0.1 & 0.616 \\
N-balance, mg/d/W $(\mathrm{kg})^{0.67}$ & 1449 & 1277 & 85 & 0.189 \\
\hline
\end{tabular}

PSEM - pooled standard error of means

${ }^{1}$ DON concentrations of the starter diets: 0.15 and $3.86 \mathrm{mg} / \mathrm{kg}$ for diets containing 0 and $40 \%$ contaminated wheat, respectively

\section{DISCUSSION}

The results of the growth experiment in which a range of practically relevant dietary DON concentrations were tested can be placed into the variability of literature data dealing with DON concentrations around $1 \mathrm{mg} / \mathrm{kg}$ diet. No consistent effects of dietary DON concentration seem to exist within this dietary DON range on the performance of pigs and piglets as reviewed by Dänicke et al. (2001). In the present study, total liveweight gain decreased by $-3.9 \%$ at a dietary DON concentration of $0.7 \mathrm{mg} / \mathrm{kg}$, by $-1.9 \%$ at the next DON concentration of $1.2 \mathrm{mg} / \mathrm{kg}$, by $-3.9 \%$ at $2.5 \mathrm{mg} / \mathrm{kg}$ and $-7.8 \%$ at $3.7 \mathrm{mg} / \mathrm{kg}$. Thus, it would appear that the effects of DON became obvious when the dietary DON concentration exceeded $2.5 \mathrm{mg} / \mathrm{kg}$. On the other hand, pigs fed the other DON contaminated diets $(0.7,1.2$ and $2.5 \mathrm{mg} / \mathrm{kg})$ collectively performed more poorly than the control group. It must be considered in evaluating the results that the contaminated wheat contained approximately $1.6 \mathrm{mg} 3$-acetyl-DON per $\mathrm{kg}$ DM in addition to the $7.79 \mathrm{mg}$ DON. If ingested 3-acetyl-DON appears in the systemic blood of pigs exclusively as the de-acetylated DON (Eriksen et al., 2002), then it seems reasonable to assume a similar toxicity of 3-acetyl-DON for the pig than for ingested un-acetylated DON. This would increase the calculated DON level of 
each diet containing contaminated wheat by approximately $20 \%$, assuming a $100 \%$ conversion of 3-acetyl-DON to DON. However, no attempts have been made to correct DON concentration of diets or DON intake for 3-acetyl-DON in the view that this toxin was analysed by another method than DON. Therefore, DON balance data and effective dietary DON concentrations could be biased to some extent.

This problem also makes clear that analysed DON can only be taken as an indicator mycotoxin suggesting that more than one or two analysed mycotoxins might be present in the particular contaminated feedstuff. The apparently stimulating effect of the diets containing DON on feed intake during the starter period should be viewed rather as an increase in feed consumption than in real feed intake. It was observed that pigs offered diets containing DON tended to rummage and to sniff in the feed when offered in the trough. Thus, feed waste was probably higher in these groups, which not only resulted in a higher recorded level of feed intake, but also in an increased feed to gain ratio and a concomitant decrease in liveweight gain. During the later fattening period, pigs might have given up such a behaviour and gotten accustomed to the diet to some extent. The view of increased feed waste is further substantiated by the fact that the nutritive value of the most differing diets was similar (Table 6). The effect of DON on feed intake was eliminated in the balance study by adjusting all animals to the voluntarily consumed feed intake level, i.e. to the level of the DON fed pigs. Consequently, the distinctly increased feed to gain ratio of the DON fed pigs during the starter period of the growth experiment might be related to the increased feed consumption caused by a diet-related increase in feed wastage.

The effects of DON contaminated feedstuffs on nutrient digestibility were only rarely examined and the observed results were inconsistent. For example, Friend et al. (1986) found the DM digestibility of pigs to be reduced in the presence of DON whereas Dänicke et al. (2004a) found no or inconsistent effects of graded levels of DON in pig diets on nutrient digestibility. On the other hand, Dänicke et al. (2004b) reported a DON related significant increase in nutrient digestibility. In all of these studies, naturally contaminated cereals were used as a mycotoxin source. However, the respective uncontaminated control batches were obtained from other sources, i.e. the variety, the location of cultivation and agro-technical treatments of the contaminated and uncontaminated cereal were not fully comparable. Therefore, such variables could interfere with direct DON effects or other effects caused by the fungal growth on nutrient digestibility. Thus, the results of the present balance study are only related to the fungal growth and secondary metabolism (DON contamination) since the control batch and the contaminated batch were harvested from the same plot. Therefore, it can be concluded that neither the presence of Fusarium toxins nor the fungus growthrelated changes in chemical composition and physical characteristics of the 
contaminated wheat (Table 2) caused an altered feed value for the pig. Therefore, variability as reported in the literature might be related, at least in part, to factors others than those related to the fungus.

The results of the present investigation of the DON metabolism employing steady state conditions (quantitative balance of constant DON intake and DON excretion with urine and faeces over seven days) are in general agreement with the results of toxico-kinetic studies where the urinary DON excretion was identified as the main toxin elimination route. For example, the urinary recovery of a DON bolus was found to vary from 28 to $57 \%$ (Coppock et al., 1985) and from 54 to $82 \%$ (Prelusky et al., 1988). The urinary recovery of ingested DON varied between 50 and $63 \%$ (Friend et al., 1986), and 37 and 49\% (Shehata, 2001), 45 and 55\% (Dänicke et al., 2004a), 39 and 90\% (Dänicke et al., 2004b), obtained from balance studies. De-epoxy-DON was either not analysed or not detected in urine, which contributes to variation in recovery, although the percentage of de-epoxy-DON of the excretion of the sum of DON plus de-epoxy-DON seems to be rather low and varied from 0 to $1.1 \%$ (Dänicke et al., 2004b), from 0 to $4.1 \%$ (Dänicke et al., 2004a) and from 0 to $6.5 \%$ in the present study (Table 5 ). Moreover, the mentioned metabolite ratio agrees with the metabolite profile obtained from porcine urinary spot samples. Razzazi et al. (2002) found a mean ratio of five percent and from the results reported by Döll et al. (2003), a variation of between 3.7 and $5.4 \%$ can be calculated.

In contrast, de-epoxy-DON accounted for the majority of excretion of ingested DON as the ratio between de-epoxy-DON and the sum of DON and de-epoxy-DON was found to range between 38 and $75 \%$ (Eriksen et al., 2003) and between 94 and 100\% in the present study (Table 5). In the latter experiment, only DON and de-epoxy-DON were detected in the faeces after oral exposure to pure 3-acetyl-DON. Dänicke et al. (2004c) examined digesta of consecutive segments of the digestive tract of pigs after an oral DON bolus from contaminated wheat and found the de-epoxy-DON proportion increased from nearly zero in the proximal small intestine to approximately $80 \%$ in rectum. Moreover, it was found that DON was almost completely absorbed in the proximal small intestine where practically no de-epoxydation occurs, which would also explain the low proportion of the de-epoxydized metabolite in urine on one hand, and of low total DON/de-epoxy-DON recovery with the faeces on the other hand, as observed in the present study and reported by the other cited studies. Thus, although de-epoxydation of DON is considered as a detoxification, it is probably of only minor importance for the pig, since this process occurs primarily in segments of the digestive tract where only minor amounts pass through. DON concentration in serum was proven to be a reliable indicator of DON exposition of pigs (Figure 1). Comparable linear relationships between dietary DON and DON concentration in serum were reported by Döll 


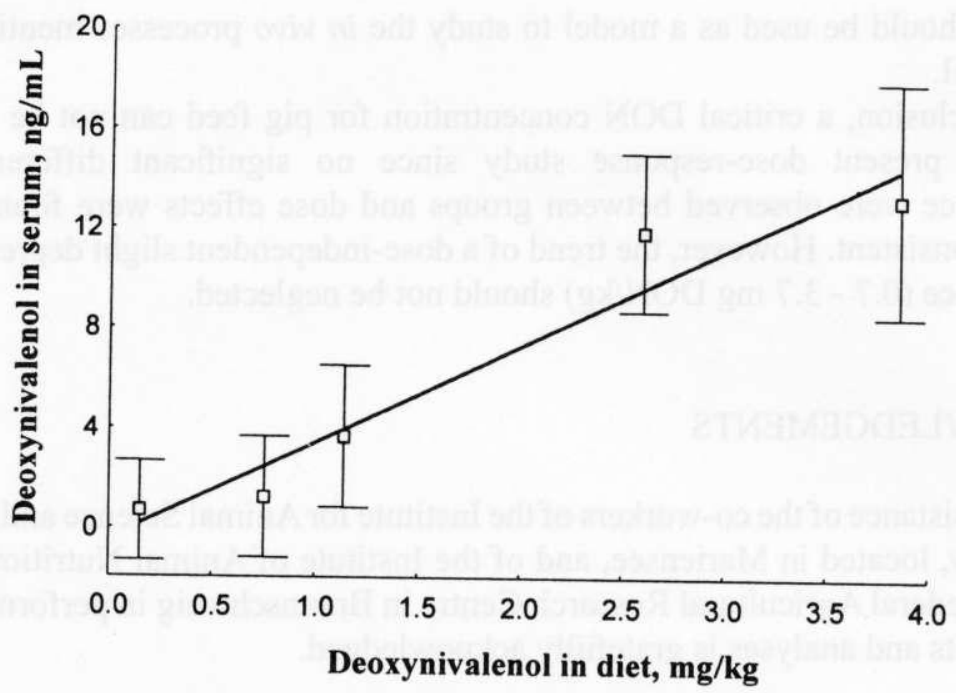

Figure 1. Deoxynivalenol concentration in serum in response to increasing dietary deoxynivalenol concentrations $\left(y=-0.43+3.86 x ; r^{2}=0.72\right)$

et al. (2003) and Dänicke et al. (2004a). However, the presence of any DON in serum does not necessarily indicate an acute or chronic DON intoxication since DON concentration in serum does not correlate with performance parameters such as feed intake or liveweight gain, and even pigs exposed at a low level might be DON-positive. Moreover DON concentration in serum was not related to any of the examined serum-clinical parameters. This was not surprising since none of these parameters responded to increasing dietary proportions of DON. Obviously, even the highest inclusion rate of contaminated wheat did not cause liver damage or impair the immune system based on the parameters examined. However, this does not necessarily imply that the immune system was not affected, since serum concentrations of immunoglobulins must be viewed as the net balance between synthesis, degradation and body distribution. It is known from in vitro studies using mice lymphocytes, that lymphocyte proliferation as such can be depressed by DON, but cytokine synthesis by T-lymphocytes might be enhanced at the same time due to a depressed interleukin repressor protein synthesis (for review see Rotter et al., 1996). This, in turn was shown to induce an increased IgA synthesis by T-lymphocytes which could increase its serum concentration if the other mentioned turnover processes are considered to remain constant. Increased serum IgA concentrations or increased IgA synthesis due to DON is suspected to be linked to IgA nephropathy (Rotter et al., 1996).

The question of whether a chronic oral exposure to low doses of DON might have consequences on the genesis of this disease in human remains to be answered, 
and pigs should be used as a model to study the in vivo processes mentioned in more detail.

In conclusion, a critical DON concentration for pig feed can not be derived from the present dose-response study since no significant differences in performance were observed between groups and dose effects were found to be rather inconsistent. However, the trend of a dose-independent slight depression in performance $(0.7-3.7 \mathrm{mg} \mathrm{DON} / \mathrm{kg}$ ) should not be neglected.

\section{ACKNOWLEDGEMENTS}

The assistance of the co-workers of the Institute for Animal Science and Animal Husbandry, located in Mariensee, and of the Institute of Animal Nutrition of the German Federal Agricultural Research Centre in Braunschweig in performing the experiments and analyses is gratefully acknowledged.

\section{REFERENCES}

Ausschuss für Bedarfsnormen der Gesellschaft für Ernährungsphysiologie, 1987. Empfehlungen zur Energie- und Nährstoffversorgung der Schweine. DLG-Verlag Frankfurt (Main)

BML, 2000. The German Federal Ministry of Agriculture: Orientation values for critical concentrations of deoxynivalenol and zearalenone in diets for pigs, ruminants and gallinaceous poultry. VDM $27 / 00,2-3$

Coppock R.W., Swanson S.P., Gelberg H.B., Koritz. G.D., Hoffman W.E., Buck W.B., Vesonder R.F., 1985. Preliminary study of the pharmacokinetics and toxicopathy of deoxynivalenol (vomitoxin) in swine. Amer. J. Vet. Res. 46, 169-174

Dänicke S., Gareis M., Bauer J., 2001. Orientation values for critical concentrations of deoxynivalenol and zearalenone in dicts for pigs, ruminants and gallinaceous poultry. Proc. Soc. Nutr. Physiol. 10, 171-174

Dänicke S., Valenta H., Klobasa F., Döll S., Ganter M., Flachowsky G., 2004a. Effects of graded levels of Fusarium toxin contaminated wheat in diets for fattening pigs on growth performance, nutrient digestibility, deoxynivalenol balance and clinical serum characteristics. Arch. Anim. Nutr. 58, 1-17

Dänicke S., Valenta H., Döll S., Ganter M., Flachowsky G., 2004b. On the effectiveness of a detoxifying agent in preventing fusario-toxicosis in fattening pigs. Anim. Feed Sci. Tech. 114, 141-157

Dänicke S., Valenta H., Döl1 S., 2004c. On the toxicokinetics and the metabolism of deoxynivalenol (DON) in the pig. Arch. Anim. Nutr. 58, 169-180

Döll S., Dänicke S., Ueberschär K.-H., Valenta H., Schnurrbusch U., Ganter M., Klobasa F., Flachowsky G., 2003. Effects of graded levels of Fusarium toxin contaminated maize in diets for female weaning piglets. Arch. Anim. Nutr. 57, 311-334

Eriksen G.S., Pettersson H., Johnsen K., Lindberg J.E., 2002. Transformation of trichothecenes in ileal digesta and faeces from pigs. Arch. Anim. Nutr. 56, 263-274 
Eriksen G.S., Pettersson H., Lindberg J.E., 2003. Absorption, metabolism and excretion of 3-acetyl DON in pigs. Arch. Anim. Nutr. 57, 335-345

Friend D.W., Trenholm H.L., Thompson B.K., Prelusky D.B., Hartin K.E., 1986. Effect of deoxynivalenol (DON)-contaminated diet fed to growing-finishing pigs on their performance at market weight, nitrogen retention and DON excretion. Can. J. Anim. Sci. 66, 1075-1085

Klobasa F., 1987. Methodische und gerätetechnische Probleme und Erfahrungen bei der Anwendung immunologischer Verfahren in der Tierzuchtforschung. Landbauforsch. Völkenrode 37, 1-17

Klobasa F., Habe F., Werhahn E., 1983. Immunglobulinkonzentrationen im Blutserum von Sauen. Landbauforsch. Völkenrode 33, 243-250

Mancini G., Carbonara O.A., Heremans J.J., 1965. Immunochemical quantitation of antigens by single radial immunodiffusion. Immunochemistry 2, 235-254

Matthäus K., Dänicke S., Strumpf A., Valenta H., Zieseniß H., Flachowsky G., 2004. Progression of the mycotoxin and nutrient concentration in wheat after inoculation with Fusarium culmorum. Arch. Anim. Nutr. 58, 19-35

Naumann C., Bassler R., 1993. Die chemische Untersuchung von Futtermitteln. VDLUFA-Verlag, Darmstadt (Germany)

Prelusky D.B., Hartin K.E., Trenholm H.L., Miller J.D., 1988. Pharmacokinetic fate of ${ }^{14} \mathrm{C}$-labeled deoxynivalenol in swine. Fund. Appl. Toxicol. 10, 276-286

Razzazi E., Böhm J., Kettner B., Hochsteiner W., Kahlbacher H., 2002. Metabolisierung von Deoxynivalenol beim Schwein: Bestimmung von DON und DOM-1 im Urin vom Schwein. Mycotox.Res. 18A, 84-88

Rotter B.A., Prelusky D.B., Pestka J.J., 1996. Toxicology of deoxynivalenol (vomitoxin). J. Toxicol. Environ. Health Pt. A 48, 1-34

Schiemann R., 1981. Methodische Richtlinien zur Durchführung von Verdauungsversuchen für die Futterwertschätzung. Arch. Anim. Nutr. 31, 13-18

Schmidt E., 1970. Glutamat-Dehydrogenase - UV-Test. In: H.U. Bergmeyer (Editor). Methoden der enzymatischen Analyse. Verlag Chemie, Weinheim (Germany), pp. 607

Schollenberger M., Lauber U., Terry Jara H., Suchy S., Drochner W., Müller H.-M., 1998. Determination of eight trichothecenes by gas chromatography-mass spectrometry after sample clean-up by a two-stage solid-phase extraction. J. Chromatogr. A 815, 123 - 132

Shehata S., 2001. Detoxification of mycotoxin contaminated animal feedstuffs. PhD. Thesis, Faculty of Agriculture, Zagazig University (Egypt)

StatSoft Inc., 1994. Statistica for the Windows ${ }^{\mathrm{TM}}$ Operating System. Tulsa, OK (USA)

Szasz G., Weimann G., Stahler F., Wahlefel A.W., Persijn J.P., 1974. New substrates for measuring gamma-glutamyl transpeptidase activity. Z. Klin. Chem. Klin. Biochem. 12, 228

Valenta H., 1999. Zum Einfluß des Extraktionsmittels auf die Bestimmung von Zearalenon in Getreide. VDLUFA-Kongreß3band 1999, Halle/Saale, VDLUFA-Schriftenreihe 52/1999, pp. 429-432

Valenta H., Dänicke S., Wolff J., 2002. Vergleich einer HPLC- und einer ELISA-Methode zur Bestimmung von Dcoxynivalenol in Mühlenstäuben, Kleien und Getreide. VDLUFAKongreßband 2002, Leipzig, VDLUFA-Schriftenreihe 58/2003, pp. 675-679

Valenta H., Dänicke S., Döll S., 2003. Analysis of deoxynivalenol and de-epoxy-deoxynivalenol in animal tissues by liquid chromatography after clean-up with an immunoaffinity column. Mycotox. Res. 19A, 51-55 


\section{STRESZCZENIE}

\section{Wplyw dodatku deoksynivalenolu (DON) na wzrost, wykorzystanie składników pokarmowych i przemianę DON u świń}

Pszenica kontrolna, pszenica zaszczepiona Fusarium culmorum oraz pszenica zanieczyszczona DON były dodawane do diety w takich ilościach, aby stężenie DON wzrastało stopniowo $(0,2 ; 0,7$; 1,$2 ; 2,5$ oraz $3,7 \mathrm{mg} / \mathrm{kg}$ ), przy czym udział ziarna pszenicy w diecie wynosił $400 \mathrm{~g} / \mathrm{kg}$. Doświadczenie przeprowadzono na tucznikach o m.c. od 34 do $104 \mathrm{~kg}$, po 18 zwierząt w grupie. Krew pobierano z żyły jarzmowej po 5 tygodniach podawania diet doświadczalnych celem oznaczenia klinicznych i chemicznych wskaźników oraz stężenia DON. Ponadto przeprowadzono doświadczenia bilansowe na świniach otrzymujących dawki z najmniejszą i największą ilością DON, oznaczając strawność składników pokarmowych oraz bilans DON.

Przyrosty m.c. tuczników nie zależały w sposób istotny od stężenia DON w diecie, choć wystapiła tendencja do ich zmniejszenia w miarę zwiększania udziału DON w diecie. Bylo to szczególnie widoczne przy skarmianiu diety zawierającej $3,7 \mathrm{mg}$ DON $/ \mathrm{kg}$; pobranie tej diety było o 5\% gorsze, a przyrosty o $8 \%$ mniejsze niż u tuczników z grupy kontrolnej. Stężenie albuminy, białka całkowitego, GLDH, ASAT, $\gamma$-GT oraz immunoglobiny w surowicy krwi nie zależało od rodzaju skarmianej diety, natomiast stężenie DON wzrastało wraz. z jego zwiększającym się udziałem w diecie.

Nie stwierdzono istotnych różnic w strawności składników pokarmowych w zależności od skarmianej diety.

Z pobranego DON - 52,3\% było wydalane jako DON, $92,6 \%$ jako metabolit de-cpoksy-DON u świń otrzymując największą dawkę DON $(3,7 \mathrm{mg} / \mathrm{kg})$. Wydalanie tych związków stanowiło około $98 \%$ ilości DON oznaczonej w moczu i kale, przy czym DON wydalany był głównie w moczu. Ilość de-epoksy-DON wynosiła około $5 \%$ wydalanego tego związku plus DON w moczu, podczas gdy w kale około $97 \%$, co wskazuje na znaczenie przewodu pokarmowego w przemianach DON u świń. 